\title{
INTEGRATING CUSTOMER RELATIONSHIP MANAGEMENT AND REVENUE MANAGEMENT: A HOTEL PERSPECTIVE
}

\author{
Breffni M. Noone \\ Cornell University \\ Sheryl E. Kimes \\ Cornell University \\ Leo M. Renaghan \\ Cornell University
}

A number of authors have advocated a move towards integrating customer relationship management (CRM) and revenue management (RM). The implications of integrating CRM and RM strategies in the context of the hotel environment, however, have received little attention. The key questions that need to be addressed are: who should be targeted with CRM efforts and how will those efforts affect the RM process? This paper examines the relationship between CRM and RM. By means of the life time/profitability approach to customer segmentation proposed by Reinartz and Kumar in 2002, the appropriate customer segments to target with CRM efforts are identified and a supporting RM strategy is outlined for each segment. These include traditional RM, lifetime value-based pricing, availability guarantees and short-term and ad hoc promotions. The impact of these RM strategies on business processes in relation to customer segmentation, demand forecasting, information systems management and human resource management is addressed.

KEYWORDS: customer relationship management, revenue management, customer loyalty, customer lifetime value, hotels 


\section{INTRODUCTION}

An increasing number of hotel organizations are developing customer relationship strategies and investing in supporting customer relationship management (CRM) technologies in an endeavor to foster customer loyalty and maximize long-term profits (Rodriguez, 2002a, 2002b; Terrero, 2002a). Inherent in the relationship management process is the management of revenue streams from customers. There is, however, little evidence to suggest that hotel companies are systematically incorporating revenue management (RM) considerations into their CRM strategies (Dickinson, 2001), with the exception of Harrah's Entertainment, which is leading the hospitality field in terms of its integrated CRM/RM strategy (Anon., 2002). The importance of integrating CRM and RM strategies has been noted by a number of authors (Dickinson, 2001; Jonas, 2001; Belobaba, 2002, Lieberman, 2002); however, the implications of integration of the two strategies for hotel organizations have received little attention.

The purpose of this paper is to examine the relationship between CRM and RM and identify the key issues underlying the implementation of a CRM/RM strategy in a hotel environment. The paper begins with a review of the key components of CRM and a discussion of the relationship between CRM and RM in a hotel environment. The identification of appropriate customer segments to target with CRM efforts and the supporting RM strategies to apply to each segment is then discussed. The focus is on transient customers, defined for the purpose of this paper as customers who do not benefit from the fixed rates or availability guarantees typically negotiated with hotels by wholesale travel companies and large-volume corporate accounts. The impact of implementing segment-specific RM strategies on existing business processes including 
customer segmentation, forecasting, information management and human resource management will also be addressed.

\section{CUSTOMER RELATIONSHIP MANAGEMENT}

The goal of CRM is to align business processes and customer strategies for long-term customer loyalty and profitability (Rigby et al., 2002). Customer relationship managementrelated customer strategies include tailoring the physical product and service delivery process to the specific needs and preferences of individual customers and developing customized marketing communications at the individual customer level (Haley and Watson, 2002; Oliva, 2002). The number of hotels investing in the development of structured CRM programs has increased over the past five years, with many hotel organizations implementing one or all of these customer strategies (Songini, 2001). For example, Radisson International identifies three components in its CRM program: recognition and personalized service, incentives and customized dialogue (Adams, 2001). Wyndham International provides members of its By Request guest recognition program with the facility to fill out their profiles on line, through a wireless connection or by calling a toll-free number. This information is then used to enhance the guests' experience during their stay at any of the properties in the group and is also used by reservation agents, eliminating standard questions such as preferred room type and smoking preference during the reservation process (Oliva, 2002). Similarly, Rosewood Hotels and Resorts sends its guest questionnaires requesting information on preferences such as pillow type, beverage type in the minibar and special dietary requirements prior to arrival (Marsan, 2000). 
The ability of hotel organizations to provide consistent recognition and differential treatment for individual customers requires that an appropriate technological infrastructure be in place to facilitate the collection of, and access to, customer information. Data collection and maintenance has been identified as a critical component of CRM (Haley and Watson, 2002). The key issue in terms of technology deployment is the integration of enterprise-wide systems, including property management, point of sales and central reservation systems to provide a single view of the customer within and across hotels and across distribution channels. A number of hotel companies including Hilton Hotels Corporation, Choice Hotels International and Carlson Hospitality Worldwide have invested in CRM systems and data warehouse technology to provide central repositories for customer data and data mining capabilities that facilitate targeted marketing campaigns and personalized communications with customers (Inge, 2001; Songini, 2001; Terrero, 2002b)

\section{CUSTOMER RELATIONSHIP MANAGEMENT AND REVENUE MANAGEMENT: COMPLEMENTARY BUSINESS STRATEGIES}

While many hotel organizations are placing increasing emphasis on the implementation of CRM, it appears that there has been little consideration of the impact of CRM practices on organizations' existing RM strategy. Hotels have two strategic levers for managing revenue: duration control and demand-based pricing (Kimes and Chase, 1998; Kimes et al., 1998). The typical application of RM for transient customers is that rate and inventory availability are dictated by forecast demand in the market. This RM model is oblivious to the specific characteristics or value of the customer (Karadjov and Hornick, 2000). While this approach 
maximizes the room revenue generated from a single transaction, it may not lead to optimal long-term gains. Consider the following. The high-demand forecast for a given day results in either denied availability or a high-rate quote to a particular customer, with no consideration of the high lifetime value (LTV) of that customer to the hotel. The PM objective has been achieved. Short-term revenue has been maximized. The net result, however, will be decreased long-term revenues if that high-value customer chooses, either through price resistance or lack of room availability, to switch to a competitor.

Consideration of the value of customer relationships to hospitality organizations has generated a move towards the integration of CRM and RM in the gaming industry, with Harrah's Entertainment the current industry leader (Anon., 2002). Its `Total Rewards' program enables customer play to be tracked across all properties, with over 70 per cent of the organization's revenue currently tracked through the program (Anon., 2002). Detailed customer information is captured, including how often each customer visits its casinos, when they come, how much they gamble and whether they win or lose. This information is matched with information relating to the customer's age, demographic profile and socio-economic group, enabling the company to calculate the potential 'lifetime value' of each customer (London, 2002; Maselli, 2002). Customers are assigned to one of approximately 100 different customer segments, based on their theoretical worth, with rate and room availability, rewards and the promotional message being varied by segment. The data gleaned from the program also enable the organization to analyze customer preferences, anticipate desired hard and soft benefits and identify cross-sell opportunities (Anon, 2002). 
Airlines have also begun to explore the integration of CRM and RM strategies. For example, Accenture is focusing on linking individual customer preferences and specific price elasticity to airline pricing and using customer no-show information for better prediction of seat availability on a given flight. They predict that the potential benefits of their customer-centric RM philosophy for airline clients could add from 4 per cent to 33 per cent in incremental revenue, with an estimated average of 8 per cent Jonas, 2001).

At present, hotel companies are developing targeted promotions as part of their CRM strategy, offering specific customers discounted rates to increase capacity utilization during periods of low demand. Management of rate and room availability on an individual customer basis in the context of the generic reservation process, however, has received little attention. Prior to consideration of potential strategies for managing the revenue streams from individual customers, hotels need to establish the long-term value of each customer relationship.

\section{CUSTOMER RELATIONSHIP MANAGEMENT AND CUSTOMER LOYALTY}

As a fundamental component of its CRM strategy, an organization must establish a means of ranking customers to identify the most valuable and then servicing them differentially (Haley and Watson, 2002). The tradition of hospitality is to value every customer and deliver outstanding service to all, but in practice it simply is not possible. That does not automatically imply that some customers should receive bad service but that, given the resource constraints of many organization, the bulk of the investment should be in the customers that can generate the greatest return on investment, measured in terms of profit. 
It is a widely held belief that loyal customers are an organization' most profitable customers, that they cost less to serve, are usually willing to pay more than other customers and often generate new business via word-of-mouth recommendations (Reinartz and Kumar, 2002). These benefits are frequently cited as the foundation for pursuing customer loyalty initiatives (e.g. Schlesinger and Heskett, 1991; Clark and Payne, 1994; Kotler and Armstrong, 1994; Bowen and Shoemaker, 1998; Gwinner et al., 1998; Johnson, 1998). Reichheld and Teal's study (1996), however, appears to be the only well-documented empirical evidence to substantiate the hypothesized positive life-- time-profitability relationship (Reinartz and Kumar, 2000). The contention that loyal customers are always more profitable may be a gross over-simplification (bowling and Uncles, 1997). Empirical research undertaken by Reinartz and Kumar (2002) indicates that the relationship between loyalty and profitability may be much weaker than loyalty program proponents' claim. They discovered little evidence to suggest that regular customers were cheaper to serve, were less price sensitive or provided more word-of-mouth marketing. On the basis of their results, they advocate that management, instead of focusing on loyalty alone, should measure the relationship between loyalty and profitability in order to better identify the appropriate customers on which to focus. The first step towards achieving this objective is to identify the organization's loyal customer base.

\section{Measuring customer loyalty}

The structure of an organization's loyal customer base is a function of how loyalty is defined by the organization. Customer loyalty is generally defined in behavior or attitudinal terms or some combination of the two. Measures of behavioral loyalty include volume and frequency of purchase over time (Riley et al., 2001), proportion of consumption within a 
specified set of other goods and services located within a defined market (Howard et al., 1988; Backman and Crompton, 1991), probability of repeat purchase and combinations of the first three measures. Attitudinal loyalty can be measured using a simple attitudinal statement of loyalty toward the service provider (Guest, 1942; Day, 1969; Pritchard and Howard, 1997) or by measuring the commitment to the organization (Pritchard and Howard, 1993; Selin et al., 1988). Research suggests that a two-dimensional view of loyalty, incorporating behavior and attitude, will lead to the identification of truly loyal customers (see Day, 1969; Pritchard and Howard, 1997). The development of a loyalty matrix such as that proposed by Pritchard and How and (1997) will enable hotels to segment customers by degree of loyalty: true, latent, spurious and low (see Figure 1).

Some companies use membership of their loyalty programme as the measure of customer loyalty. This, however, may not be an appropriate proxy measure. First, since members of frequency programs represent a self-selected group, they are unlikely to represent an organization's entire loyal customer base. For example, it was reported that 5 per cent of a major airline's customers were paying full fare but were not loyalty club members, so the airline did not know who they were (Feldman, 2002). Secondly, frequency programme membership does not guarantee that a customer is actually loyal to the hotel. A customer's loyalty may be to the incentive rather than to the hotel (Javalgi and Moberg, 1997). This type of forced relationship may lead to short-term loyalty, as it will not prevent customer patronage of a competing organization (Kandampully, 1998). Once points are cashed in, the customer may be vulnerable to competitor's offerings (Dube and Shoemaker, 1999). 
Quantifying customer relationships Lifetime value is the most frequently used measure to quantify the value of customer loyalty (Shoemaker and Lewis, 1999). Individual customer lifetime profits are typically modelled as a function of a customer's lifetime duration, revenue flows over the course of a customer's lifetime and the organization's costs associated with the marketing exchange (Gordon, 1988; Wyner, 1999; Reinartz and Kumar, 2000). The customer LTV is then calculated in current dollars.

The potential role of LTV analysis in customer relationship investment decisions is exemplified in the following example (the figures used are for illustrative purposes only). John and Mary are customers of Hotel A, both paying an average room rate of $\$ 150$ per stay at the hotel. John stays at the hotel twenty times per year and has been doing so for the last ten years. Based on his average profit per stay and his estimated lifetime duration, his LTV is $\$ 19,500$. Mary stayed at the hotel four times in the last three years. Based on her average profit per stay and her estimated lifetime duration, her LTV has been calculated as $\$ 2,250$. On the basis of room rate alone, John and Mary could be considered of equal value to the hotel, suggesting that they should receive equivalent treatment. While both customers are profitable for the hotel, however, the considerably greater value associated with John, when LTV is factored in, suggests that the hotel should dedicate more resources in maintaining the relationship with him. While this simplified example illustrates the advantage of estimating customer LTV as a key input to customer relationship investment decisions, the challenge in using LTV lies in the establishment of an appropriate methodology for assigning costs to customers and the estimation of customer life-- time duration. 
If disaggregated cost information is not available, hotels may consider assigning costs to customers based on individual service encounters (Storbacka, 1994) or by using activity-based costing (Cokins et al., 1993; Noone and Griffin, 1999; Zeithaml, 2000; Cockburn, 2000; Fredericks et al., 2001). A number of approaches can be used to estimate lifetime duration, including directly asking customers about their future intentions to repurchase (Jones and Sasser, 1995) or using more sophisticated statistical approaches (e.g. Schmittlein et al., 1987;

Schmittlein and Peterson, 1994; Reinartz and Kumar, 2000, 2002; Rust et al., 2001).

Hotels should also consider including indirect contributors such as word of mouth communication, customer referrals and endorsements in LTV calculations. They represent important forms of loyal customer behavior (Reichheld, 1993; Heskett et al., 1994; Duboff and Underhill Sherer, 1997; Gremler and Brown, 1999) but are frequently ignored because they are soft measures of behavior that are difficult to link to eventual purchasing behavior. They can, however, be captured through customer surveys Jones and Sasser, 1995).

Reinartz and Kumar (2002) segment customers into four categories (True Friends, Barnacles, Butterflies and Strangers) based on projected lifetime duration and lifetime profitability to identify the appropriate customers to target with CRM efforts (see Figure 2).

True Friends have a long projected lifetime duration and high lifetime profitability and represent the best fit between the company's offering and customer needs. If the claims of loyalty proponents hold true, True Friends should exhibit true loyalty. Hotels should strive to build both attitudinal and behavioral loyalty from these customers. 
Barnacles have a long projected lifetime duration and low lifetime profitability, with a limited fit between the company's offerings and customer needs. The low lifetime profitability may be related to a lack of income or a lack of willingness to spend their income. Companies should focus on identifying customers who have the potential to increase their spending.

Butterflies are profitable and have a short projected lifetime duration, with a good fit between the company's offerings and customer needs. These customers seek out the best deals, and avoid building a stable relationship with any single provider. Hotels should aim to achieve transactional satisfaction, not attitudinal loyalty, with these customers.

Strangers have a short projected lifetime duration and low lifetime profitability, with little fit between the company's offerings and customer needs. Hotels should not invest in relationships with these customers.

\section{POTENTIAL REVENUE MANAGEMENT STRATEGIES}

When the appropriate customer segments to target with CRM efforts have been identified, a supporting RM strategy should be developed for each segment. A variety of RM strategies are available, including traditional RM, LTV-based pricing, availability guarantees and short-term and ad hoc promotions.

* Traditional RM: The traditional application of RM centers on using room rate and length of stay controls to balance supply and demand. Property history and current bookings are used to forecast transient demand by day of week, room type and length of stay. Forecasted 
demand levels are then offset against available capacity to derive optimal rate and availability controls. Lifetime value-based pricing: LTV-based pricing is based on the lifetime value of a customer. Rather than the rate being a function of demand as in the traditional RM model, the rate quoted to an individual customer is a function of their lifetime value to the organization. Availability guarantees: Availability guarantees protect against the loss of customer patronage due to lack of inventory availability. Some hotel companies offer this type of service as part of their loyalty programs. For example, under Marriott's loyalty programme. Platinum members, who stay at Marriott properties 75 or more nights per calendar year, currently qualify for their brand-dependent 48-- hour or 72-hour reservation guarantee. The question is when should availability guarantees take precedence over the demand-based availability RM applications, and which customers should qualify for this benefit?

Short term and ad hoc promotions. Hotels typically engage in some type of promotional activity to build demand during slow periods. Rather than engaging in mass mailshot campaigns to every guest in their database, hotels need to select the specific customers to target. One CRMrelated approach to managing periods of low demand is to reward high-value customers with special offers during those periods. In addition to using customer value as the basis for targeted marketing, short-term and ad hoc promotions can be developed using lifetime duration and/ or share of wallet criteria. Short-term promotions are an intensive series of promotions that are over a short period of time and are targeted at profitable customers with a short lifetime duration. As hoc promotions consist of regular promotional activity carried out over a long period of time and are designed to increase the share of wallet of long-term customers. 


\section{MATCHING REVENUE MANAGEMENT STRATEGIES AND CUSTOMERS}

This paper uses the customer segmentation proposed by Reinartz and Kumar (2002) as the basis for matching RM strategies with different types of customers (see Figure 3). Individual organizations may decide to create a different number of customer segments based on their LTV or alternative customer valuation calculations. The overriding concern is to ensure that an appropriate RM strategy is developed for each segment.

Strangers: Given their low profitability and low lifetime duration, there is little opportunity to transform customers in the 'Strangers' segment into profitable customers. Hotels should apply traditional RM to these customers. In addition, no investment should be made in promotion to this segment, as a return on investment is unlikely.

Barnacles: Traditional RM is appropriate for the long-term, low-profit 'Barnacles'. In addition, hotels should not seek to sustain the relationship by offering loyalty programme benefits, but should offer ad hoc promotions during low demand periods. These promotions should only be targeted at customers whose profitability is driven by a small share of wallet rather than by a small wallet. By encouraging increased share of wallet, the hotel may be able to convert some 'Barnacles' into more profitable `True Friends'. Based on customer's historical spending patterns, hotels may focus promotional efforts on encouraging spend on ancillary products. Alternatively, promotional activity could be focused on cross selling other brands in the group, e.g. encouraging a weekday, business customer to use family-oriented hotels in the group for weekends or vacationing. The response rate and revenue generation of targeted customers should be tracked and measured against pre-set time-based minimum revenue cut-offs. 
If a targeted customer spends less than the minimum revenue cut-off, the hotel should cease investment in that customer.

Butterflies: Since 'Butterflies' are not brand-loyal, hotels should aim to achieve transactional satisfaction and should not heavily. For this reason, traditional RM, with its emphasis on pricing and availability controls, is appropriate for this segment. In addition, shortterm promotions may attract the 'Butterflies to the hotel. This type of promotional activity should enable the hotel to maximize the revenue generated from this customer group over the short expected duration of their relationship with the hotel. Marketing personnel must understand the customer profile of individual customers in the segment in order to develop product offerings that will encourage increased spend. As these are not long-term customers, time-based cut-off points should be established. Only customers that are still active' (i.e. their relationship with the hotel has not exceeded its projected duration) should be targeted.

True Friends: This segment presents the greatest profit potential for hotels and as such, warrants the most investment. Hotels should try to build both attitudinal and behavioral loyalty with True friends. For this reason, hotels should consider strong loyalty programs and examine the value of LTV-based pricing.

In addition to the benefits typically offered to hotel loyalty programme members such as room upgrades and express check-in, loyalty programs should be designed to provide `True Friends' with benefits that best match their individual needs and preferences. The data collected as part of an organization's CRM programme should enable the organization to tailor incentives to individual customers, for example, covering green fees for an avid golfer or free admission to a spa for a customer that has frequented the hotel's spa in the past. Other promotional activity, 
such as rewarding customers with discounted rates for special occasions such as anniversaries may also be appropriate.

Room availability guarantees should also be included as a component of the benefits package offered to True Friends to ensure that reservation requests are accommodated at all times. The availability guarantees currently offered by hotels through their loyalty programs typically have associated time frames and are subject to availability and property type. If the objective of offering a guarantee is to ensure that total demand from the 'True Friends' segment is captured, a restriction-free guarantee may be warranted. This approach would require that all hotels within a chain support the policy. This may not be easily accomplished, particularly in a franchise situation where franchisees may have a short-term orientation.

Hotels must also decide whether availability guarantees are to be strictly restricted to the 'True Friends' segment. Eligibility to this benefit in hotels' existing loyalty programs is typically room night based - if customers stay in the hotel a certain number of nights per year, they qualify for the benefit. This eligibility criterion, however, may not serve to isolate customers in the `True Friends' segment.

Hotels may need to consider developing a loyalty programme exclusively for customers in this segment to ensure that they receive the availability guarantee, personalized service, customized promotion and other non-monetary benefits that have been designed for them. Completely replacing a hotel's existing loyalty programme with this segment-specific programme may lead to the alienation of other customers. Therefore, a hotel could operate the two programs simultaneously or introduce another tier to the existing programme, with membership by invitation only to the 'True Friends' tier. In either case, hotels will have to 
develop a strategy for communicating eligibility to, and the benefits of, the segment-specific programme to the appropriate customers.

The provision of restriction-free availability guarantees for the `True Friends' segment would inherently replace the demand-based inventory controls of traditional RM. Additionally, hotels need to assess whether the demand-based pricing of traditional RM is appropriate for this segment. Hotels need to gain an understanding of the price sensitivity of 'True Friends'. Given the high long-term value of these customers, hotels do not want to lose their patronage due to price resistance driven by demand-based pricing. If `True Friends' are price sensitive, LTV-based pricing should be considered. Hotels may also want to consider LTV-based pricing to overcome the potential impact of negative customer perceptions of demand-based pricing on loyalty. 'True Friends' often expect to be rewarded by the hotel. Those that book close to the day of arrival may view the higher rates that they are charged as unfair when compared with the discounted rates that non-loyal bargain-seekers receive because they book earlier. The apparent 'rewarding' of non-loyal customers may lead to discontinued patronage among 'True Friends'.

Since there is likely to be intra-segment variation in customer value, the application of LTV-based pricing may require the creation of LTV buckets that group customers by LTV. The application of cluster analysis may be appropriate in identifying the optimal number of buckets to create. Rates could then be set, with customers in the highest LTV bucket receiving the most preferred rates. Hotels must also consider whether a single rate or a range of rates should be established for each bucket. A single-rate system implies only one rate per bucket, with that rate available regardless of demand levels in the marketplace. A range of rate for each bucket may 
provide a more demand-based approach to pricing, with rate availability for any given date being dictated by overall demand for hotel capacity.

\section{SEGMENT-SPECIFIC REVENUE MANAGEMENT STRATEGIES: IMPLEMENTATION CONSIDERATIONS}

The application of a segment-specific approach to RM will have a fundamental impact on a number of the organization's business processes. It requires a change in the way the organization segments its customer base and forecasts for RM. The technological requirements of operating a two-tier RM system, traditional RM and LTV RM, must be considered. In addition, the human resource management implications with respect to training requirements and the potential modification of the organization's existing incentive policy must also be addressed.

\section{Customer segmentation}

Segment-specific RM strategies will affect customer segmentation. Traditional RM requires segmentation by willingness to pay, with lower rates targeted at more price conscious customers. The use of segment-specific RM strategies implies that hotels also segment customers by lifetime duration and profitability.

\section{Forecasting}

Demand forecasting is an essential component of RM. The introduction of a restrictionfree availability guarantee policy for the 'True Friends' segment requires that hotels develop demand forecasts for this segment, adding another level of complexity to the forecasting process 
for RM. If hotels do not forecast at this level, they run the risk of overselling on high demand days, potentially incurring the cost of walking customers to other hotels and foregoing the revenue associated with those customers. The level of detail of the forecasts for this segment will be dependent on the number of rates established for each LTV bucket. Forecasts by rate, in addition to length of stay and day of week, will be required if there is a range of rates per bucket. These forecasts will be used to adjust the capacity available to the traditional RM system. Adjusted capacity data, in conjunction with the hotel's existing demand forecasting system, will determine rate availability for all other customers. If multiple-rate LTV buckets are created, demand data from the traditional RM system will be used to determine rate availability in each of those buckets.

\section{Information systems management}

The difficulty of integrating enterprise wide systems has created a challenge for organizations in their endeavors to create a single image of the customer across hotels and distribution channels. Hotel chains, including Hilton and Marriott, are actively working to standardize their technology. At a cost of $\$ 100 \mathrm{~m}$, Cendant is one of the few chains to have standardized the property management system across all its hotels (Berkman, 2000). While integration is expensive and time-consuming to achieve, particularly for hotel organizations that rely on a myriad non-compatible information systems, it is imperative not only to support the implementation of CRM, but also to facilitate the development of a LTV-based RM system. The data warehouse technology that is required to facilitate the centralization of customer data for CRM can also be used to store customer LTV-related data. In addition to integration with information systems, particularly property management systems, to facilitate the automatic 
download of customer data after each customer stay, the database should also be integrated with the hotel's accounting system and customer lifetime duration model to enable the matching of cost, duration and revenue data to determine customer LTVs.

Full integration of enterprise-wide information systems should enable real-- time tracking of customer data so that changes in customer lifetime/profit profiles can be made and enable the reassignment of customers to different segments when appropriate. Procedures for the collection of customer attitudinal data should also be established. This will help measure the success of the loyalty programme and service delivery systems in building the attitudinal loyalty of `True Friends'.

The operation of a two-tier RM system would also require information system capabilities that can adequately support simultaneous access to rate availability information for both tiers across all channels that customers use to make reservations. Hotels are already experiencing difficulties managing distribution channels and establishing single-image inventory using the traditional RM model. The addition of LTV buckets, with availability dictated by individual customer profiles, will only increase the difficulties that hotel companies are experiencing, particularly in the management of global distribution systems and other intermediary distribution channels.

\section{Training}

There are a number of training issues associated with the introduction of a two-tier RM system. Reservation agents, front-- desk clerks, RM and sales/marketing personnel, and senior management must understand the objectives of the two-tier approach and the impact it will have 
on their functional activities. Reservation and front-desk clerks, who interact directly with current and potential customers, will require training in order to manage the reservation process using the LTV RM system. Training may also have to be provided for the personnel assigned to manage and maintain the customer LTV database.

\section{Incentive policy}

The operation of a two-tier RM system may impact the hotel's approach to employee and management incentives. The successful implementation of a traditional RM system requires that reservations agents and sales managers be rewarded on revenue production (Kimes, 1997). Therefore, employee and management rewards are typically linked to overall hotel performance, measured as a function of internal RevPAR targets and RevPAR comparisons with the hotel's competitive set. The introduction of LTV RM could dilute the hotel's overall revenues in the short term, negatively impacting employee and management rewards that are dependent on short-term RevPAR performance. Hotels need to think about if, and how, the shortfall in shortterm revenues will be accounted for when establishing revenue goals and associated management and employee rewards.

From a corporate perspective, the short-term dilution in revenues will be acceptable on the premise that the long-term profitability associated with 'True Friends' will outweigh any short-term rate dilution effects. This, however, raises the issue of how performance of the twotier RM system will be measured. The impact on bottom-line profits may not be evident for a number of years. A number of performance measures could be used in the interim, however, to monitor success, including the retention rate of 'True Friends', the percentage increase in average spend of 'Butterflies' and share of wallet of 'Barnacles', and the conversion rate of 'Barnacles' to 
'True Friends'. These measures could also form the basis of the incentive programme for revenue managers and marketing personnel.

\section{CONCLUSION AND FUTURE RESEARCH}

A number of authors have advocated a move towards integrating CRM and RM (Dickinson, 2001; Jonas, 2001; Belobaba, 2002; Lieberman, 2002). Before a hotel embarks on this type of programme, however, there are a number of issues that must be addressed. Hotels first need to establish what customer relationships merit investment. Given the dearth of empirical evidence to support the claim that loyal customers are the most profitable, hotels need to quantify the value of relationships with their loyal customers before investing in them. Measurement of behavioral and attitudinal loyalty and LTV calculations will provide the data to segment customers by profitability and lifetime duration into `True Friends', 'Butterflies', 'Barnacles' or 'Strangers'. The task is then to develop appropriate CRM strategies for each segment.

A number of RM strategies can be employed to support CRM, including traditional RM, LTV-based pricing, availability guarantees and short-term and ad hoc promotions. The appropriate RM strategies to apply to a given segment will be dictated by the CRM strategy they are designed to support. The decision to introduce a CRM/RM programme should not be taken lightly. Its introduction requires a fundamental change in customer segmentation and forecasting for RM and a movement away from the traditional RM approach to rate and inventory management for the organization's most valuable customers. Management must decide which 
LTV model will be suitable for the organizational environment, and the hotel's existing IT structure must have the capability to support the implementation of an LTV RM system. It may be necessary to recruit personnel to collect customer data and manage the LTV database. The impact on employees in terms of training, job content and rewards structures needs to be assessed. In addition, any changes affecting customers must be communicated to them and must be perceived as fair for the CRM initiatives to succeed. Top management commitment is crucial to ensure company--wide buy-in and support for the programme, but this may be difficult to secure if the long-term financial benefits of the programme cannot be quantified at the outset.

While this paper highlights the fundamental issues underlying the implementation of a $\mathrm{CRM} / \mathrm{RM}$ programme, there are a number of areas where further research is required. Given that there is no universally accepted approach to LTV calculation, further work should be undertaken to establish whether there is an optimal cost allocation and duration model that can be applied to the hotel environment. The feasibility of quantifying word-of-mouth communication, customer referrals and endorsements as indirect contributors for inclusion in the LTV model requires further examination. Additional research is also needed to establish the financial implications of a CRM/RM programme. To date, there has been no empirical work that has explored the potential impact of a CRM/RM programme on the long-term profitability of hotel organizations. 


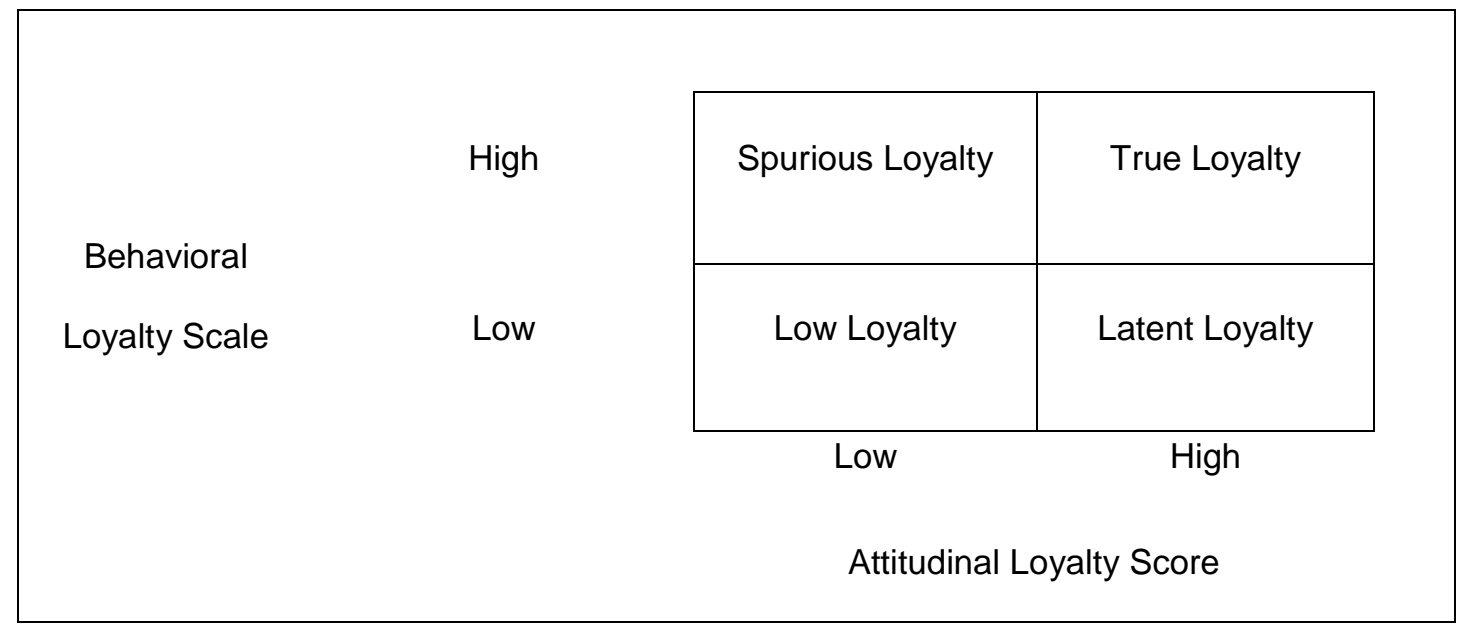

Figure 1. A typology of service loyalty (Pritchard and Howard, 1997) 


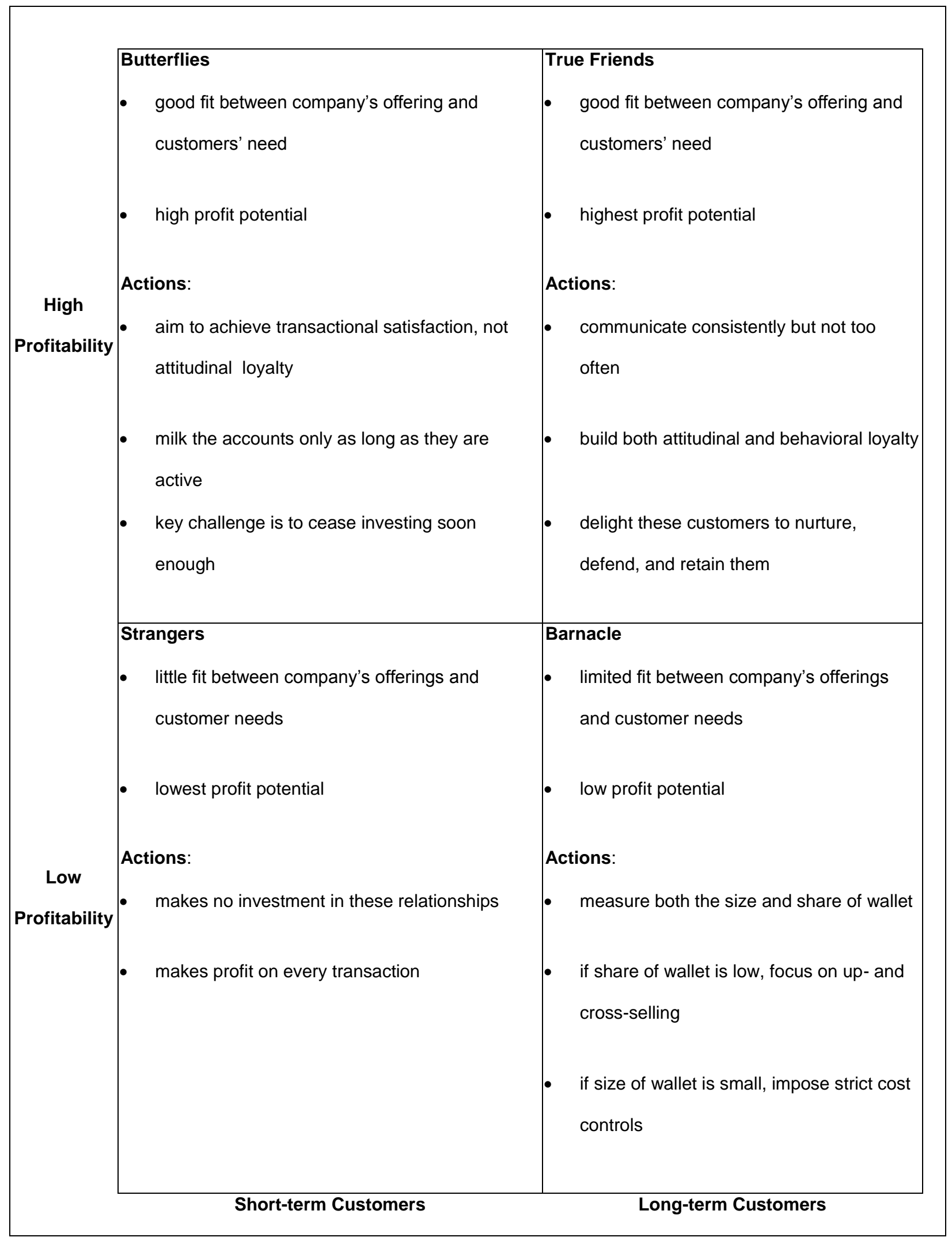

Figure 2. Choosing a CRM strategy (Reinartz and Kumar, 2002) 


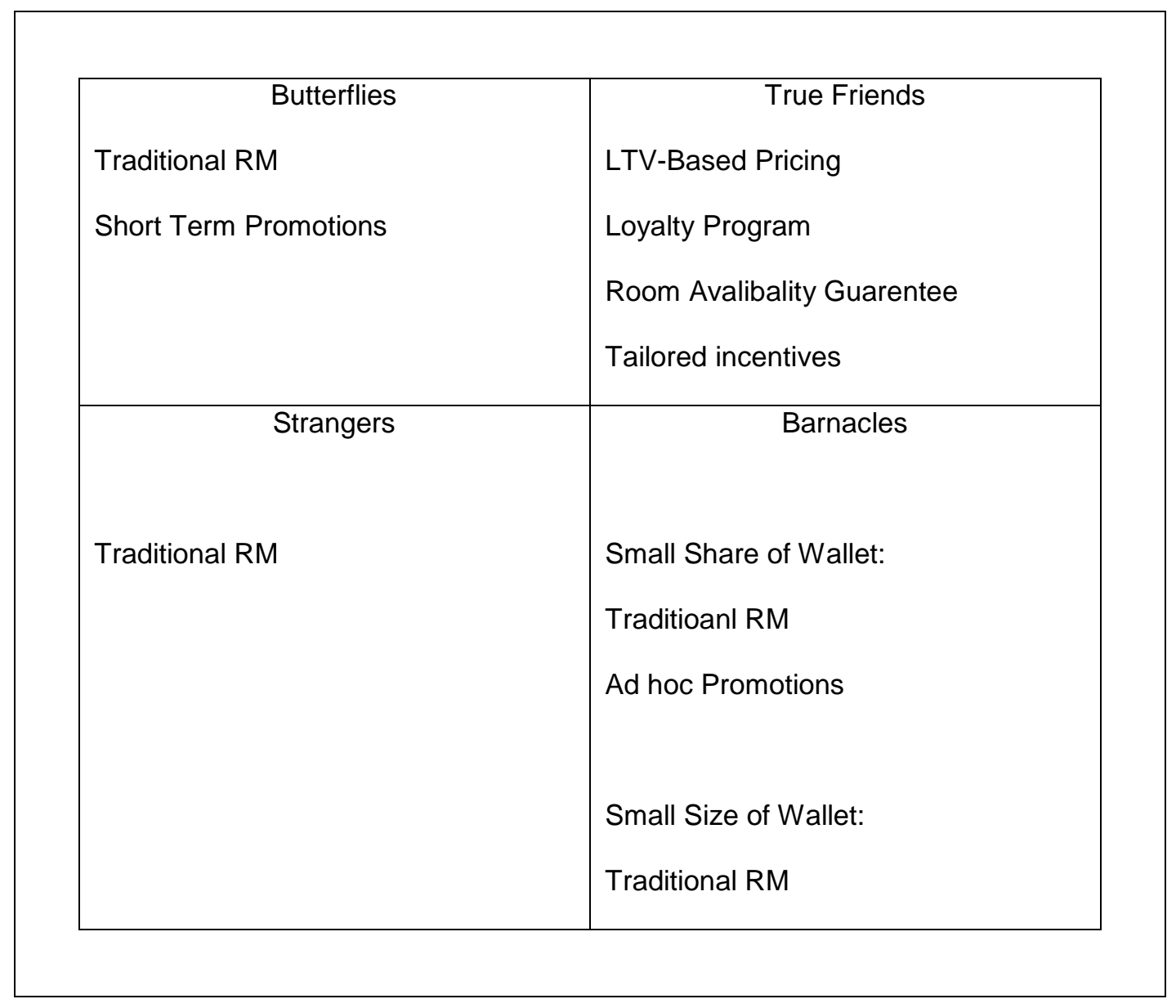

Figure 3. Segment-based RM strategies 


\section{REFERENCES}

Adams, B. (2001) 'Customer relationship management', Hotel and Motel Management, 21st May, 36-37.

Anon, (2002) 'CRM Best practices', Colloquy, 10, 2, http://www.colloquy.com

Backman, S.J. and Crompton, J.L. (1991) 'The usefulness of selected variables for predicting activity loyalty', Leisure Sciences, 13, 205-220.

Belobaba, P. B. (2002) 'Back to the future? Directions for revenue management,' Journal of Revenue and Pricing Management, 1, 87-89.

Berkman, E. (2000) 'Heartbreak hotels', CIO. 14, 6, 164-174.

Bowen, J. T. and Shoemaker, S. (1998) 'Loyalty: a strategic commitment', Cornell Hotel and Restaurant Administration Quarterly, 39, 1. 12-25.

Clark, M, and Payne, A. (1994) 'Achieving long-term customer loyalty: a strategic approach', Working Paper, enter for Services Management, Cranfield School of Management.

Cockburn, P. (2000)'CRM for profit', Telecommunications, 34, 12, 89-92.

Cokins, G.C. Stratton, A. and Helbling, J. (1993) An ABS Manager's Primer, Irwin, Chicago.

Day G.S. (169) 'A two-dimensional concept of brand loyalty', Journal of Advertising Research, 9, 3. 29-31, 34-35.

Dickinson, C. B. (2001) 'CRM-enhanced revenue management in the hospitality industry', Hospitality Upgrade, Summer, 136, 138.

Dowling, G. R. and Uncles, M. (1997) 'Do customer loyalty programs really work?', Sloan Management Review, 38, 4, 71-82.

Dube, L. and Shoemaker, S. (1999) 'Loyalty marketing and brand switching', in Swartz, T. (ed.) Handbook of Services Marketing and Management, Sage, Beverly Hills. 
Duboff, R. S. and Underhill Sherer, L. (1997) `Customized customer loyalty', Marketing Management, 6, 2, 21-27.

Feldman, J. M. (2002) 'CRM is back', www.atwonline.com, June.

Fredericks, J. O., Hurd, R. R. and Salter II, J. M. (2001) `Connecting customer loyalty to financial results', Marketing Management, 10, 1, 26-32.

Gordon, I. (1988) Relationship Marketing, Wiley, Canada.

Gremler D.D. and Brown, S. W. (1999) 'The Loyalty ripple effect: appreciating the full value of customers', International Journal of Service Industry Management, 10,3, 271-291.

Guest, L. P. (1942) 'Last vs. usual purchase questions', Journal of Applied Psychology, 26, 180186.

Gwiner, K.P., Gremler, D.D. and Bitner, M. J. (1998) 'Relational benefits in services industries: the customer's perspective', Journal of the Academy of Marketing Science, 26, 2, 101-114.

Haley, M. and Wastson, B. (2002) 'The ABCs of CRM: Part One of Two', Hospitality Upgrade, Summer, 36, 38, 40 .

Heskett, J.L. Jones T.O., Loveman, G. W., Saser, W.E. Jr and Schlesinger, L.A. (1994) 'Putting the service-profit chain to work', Harvard Business Review, 72, 2, 164-174.

Howard, D.R., Edginton, C.R. and Selin, S. W. (988) 'Determinants of program loyalty', Journal of Park and Recreation Administration, 6,41-5.

Inge, J. (2001) 'Customer relationship managements: Is your approach successful?', Hospitality Upgrade, Fall, 8, 10, 12, 14, 16, 18.

Javalgi, R. G. and Moberg, C. R. (1997) 'Service loyalty: implications for service providers', Journal of Services Marketing, 11, 3, 165-179. 
Johnson, M.D. (1998) Customer Orientation and Market Action, Prentice Hall, Upper Saddle River, NJ.

Jonas, D. (2001) 'Carriers melding revenue mgmt. and CRM systems', Business Travel News. 26th March, 18-19.

Jones, T.O. and Sasser, W.E. Jr (1995) 'Why satisfied customers defect', Harvard Business Review, 73, 6, 88-99.

Kandampully, J. (1998) 'Service quality to service loyalty: a relationship which goes beyond customer services', Total Quality Management, 9, 6, 431-443.

Karadjov, Y. and Hornick, S. (2000) 'Yield managing your customers - one at a time Hospitality Upgrade, Spring, 120, 122-123.

Kimes S. E. (1997) 'Yield management: an overview', in Yeoman, I and Ingold, A. (eds) Yield Management: Strategies for the Service Industries. Cassell. U.K.

Kimes, S.E. Chase, R. B. (1198) 'The strategic levers of yield management', Journal of Service Research, 1, 2, 156-166.

Kimes, S.E. Chase, R. B. Choi, S. Ngonsi, E. N. and Lee, P. Y. (1998) 'Restaurant revenue management', Quarterly, 40, 3, 40-45.

Kotler, P. and Armstrong, G. (1994) Principles of Marketing, Prentice Hall, Englewood Cliffs, NJ, 15.

Lieberman, W. H. (2002) 'Revenue management: What lies ahead?', Journal of Revenue and Pricing Management, 1, 2,189-195.

London, S. (2002) 'Inside Track - IT and horsepower are a winning formula', Financial Times, 11th October, 12.

Marsan, J. (2000) 'From data to dollars', Hotels, March, 91-92, 94. 
Maselli, J. (2002) `Businesses Find CRM Value in Assortment of Apps - IT managers make the most of systems that touch the customer', Information Week, 22nd April, 74.

Noone, B. and Griffin, P. (1999) `Managing the long-term profit yield from market segments in a hotel environment: a case study on the implementation of customer profitability analysis', International Journal of Hospitality Management, 18, 2, 111-128.

Oliva, R. (2002) `Branching out', Hotels, March, 71-72, 78.

Pritchard, M. P. and Howard, D. R. (1993) `Measuring loyalty in travel services: a multidimensional approach, in Sirgy, J., Bahn, K. and Erem T. (eds) World Marketing Congress, Vol. 6, Academy of Marketing Science, Blacksburg, VA, 115-119.

Pritchard, M. P. and Howard, D. R. (1997) 'The loyal traveler: examining a typology of service patronage', Journal of Travel Research, Spring, 2-10.

Reichheld, F. F. (1993) 'Loyalty-based management', Harvard Business Review, 71, 2, 64-73.

Reichheld, F. F. and Teal, T. (1996) The Loyalty Effect: The Hidden Force Behind Growth, Profits and Lasting Value, Bain and Company Inc., Harvard Business School Press, Boston, MA.

Reinartz, W. J. and Kumar, V. (2000) 'On the profitability of long-life customers in a noncontractual setting: an empirical investigation and implications for marketing', Journal of Marketing, 64, 4, 17-35.

Reinartz, W. J. and Kumar, V. (2002) `The mismanagement of customer loyalty, Harvard Business Review, 80, 7, 4-12.

Riley, M., Niininen, O., Szivas, E. E. and Willis, T. (2001) `The case for process approaches in loyalty research in tourism', International Journal of Tourism Research, 3, 23-32. 
Rigby, D. K., Reichheld, F. F. and Schefter, P. (2002) 'Avoid the four perils of CRM', Harvard Business Review, 80, 2, 101-109.

Rodriguez, D. M. (2002a) 'Starwood focuses tech efforts on CRM, property systems', Hotel Business, August, 14A,

Rodriguez, D. M. (2002b) 'Cendant restructures IT team, moves ahead on mage loyalty', Hotel Business, August, 22A.

Rust, R. T. Lemon, K. N. and Zeithmal, V. A. (2001) 'Driving customer equity: linking customer lifetime value to strategic marketing decisions', Working Paper, Report No. 01-108, Marketing Science Institute, Cambridge, MA.

Schelesinger, L. and Heskett, J. (1991) 'Breaking the cycle of failures in services', Sloan Management Review. 32, 3, 17-28.

Schmittlein, D. C. and Peterson, R. A. (1994) 'Customer base analysis: an industrial purchase process application', Marketing Science, 13, 1, 41-67.

Schmittlein, D. C. Morrison, D.G. and Colombo, R, (1987) 'Counting your customers: Who are they and what will they do next?' Management Science,33, 1. 1-24.

Selin, S. W., Howard, D. R., Udd, E. and Cable, T.T. (1988) An analysis of customer loyalty to municipal recreation programs', Leisure Sciences, 10, 217-223.

Shoemaker S. and Lewis, R.C. (1999) 'Customer loyalty: the future of hospitality marketing', Hospitality Management, 18, 345-- 370

Songini, M.L. (2001) 'Hospitality players check out CRM', Computerworld, 25th June, 6, Storbacka, K. (1994) 'The nature of customer relationship profitability, analysis of relationships and customer bases in retail banking', Working Paper, Swedish School of Economics and Business Administration, Finland. 
Terrero, R. (2002a) 'Carlson Hotels puts customers first with its technology initiatives', Hotel Business, August, 36A/

Terrero, R. (2002a) 'Choice continues to enhance technology to benefit franchisees', Hotel Business, August, 40A.

Wyner, G. A. (2000) 'Customer relationship measurement', Marketing Research, 11, 2, 39-- 41.

Zeithaml, V. A. (2000) "Service quality, profit-a ability and the economic worth of customers: what we know and what we need to learn', Journal of the Academy of Marketing Science, $28,1,67085$ 